\title{
PROPHYLACTIC REPLACEMENT OF BJÖRK-SHILEY CONVEXO-CONCAVE VALVES AT RISK OF STRUT FRACTURE
}

\author{
Marjon Kallewaard, $\mathrm{MSc}^{\mathrm{a}}$ \\ Ale Algra, MD, $\mathrm{PhD}^{\mathrm{a}}$ \\ Jo Defauw, MD $^{\mathrm{b}}$ \\ Yolanda van der Graaf, $\mathrm{MD}, \mathrm{PhD}^{\mathrm{a}}$ \\ Björk-Shiley Study Group ${ }^{c}$
}

\begin{abstract}
Objective: Prophylactic replacement of Björk-Shiley convexo-concave valves (Shiley, Inc., Irvine, Calif.) has been advised for selected groups of patients. If prophylactic replacement is considered, risks of postoperative morbidity and mortality have to be weighed against benefits of replacement. Here we report the results of prophylactic replacement of Björk-Shiley convexoconcave valves at risk of strut fracture in The Netherlands. Methods: We reviewed medical records of 36 patients undergoing prophylactic replacement of their Björk-Shiley convexo-concave valves before August 1995. Replacement was judged to be prophylactic if the risk of strut fracture outweighed that of death from reoperation, or the patient wished to have the valve replaced although it was not recommended. The procedure was also considered to be prophylactic if a concomitant pathologic condition, not likely to require cardiac surgery in the near future, was present or if preoperative examination revealed an unexpected cardiac pathologic condition. Results: Twenty-two 70-degree and 16 60-degree Björk-Shiley convexo-concave valves and one spherical valve were replaced (25 aortic and 14 mitral, including three double-valve replacements). Early mortality was $2.8 \%(1 / 36)$ (exact $95 \%$ confidence interval [CI] 0.1 to 14.5). Mean follow-up was 33 months. One- and 3-year survivals were 94\% (95\% CI 79\% to 99\%) and $91 \%(95 \%$ CI $74 \%$ to $97 \%$ ), respectively. All three deaths were sudden. Conclusions: If special care is taken in selecting patients, the risk of prophylactic replacement is comparable to that of primary valve replacement. More data are needed to assess whether the risk of sudden death is possibly increased. (J Thorac Cardiovasc Surg 1998;115:577-81)
\end{abstract}

$\mathrm{R}$ eplacement of prosthetic heart valves in general carries a higher risk of death and morbidity than primary valve replacement. ${ }^{1,2}$ For some recipients of the Björk-Shiley convexo-concave (BScc) valve (Shiley, Inc., Irvine, Calif.), nevertheless, the risk of fracture of the outlet strut of their valve(s) may outweigh the risk of mortality and morbidity associated with valve replacement, and prophylactic re-

From the Julius Center for Patient Oriented Research, Clinical Epidemiology Unit, Utrecht University, ${ }^{\text {a }}$ Utrecht, and Department of Cardiothoracic Surgery, the St Antonius Hospital, ${ }^{\text {b }}$ Nieuwegein, The Netherlands. Members of The Netherlands Björk-Shiley Study Group ${ }^{c}$ are listed in the appendix.

Received for publication April 14, 1997; revisions requested June 19, 1997; revisions received July 28, 1997; accepted for publication August 27, 1997.

Address for reprints: Marjon Kallewaard, Julius Center for Patient Oriented Research, Utrecht University, PO Box 80035, 3508 TA Utrecht, The Netherlands.

Copyright (C) 1998 by Mosby, Inc.

$0022-5223 / 98 \$ 5.00+0 \quad \mathbf{1 2 / 1 / 8 5 6 7 9}$ placement has been recommended. ${ }^{3-8}$ The risk of prophylactic replacement, however, is unknown.

Since 1991, several Dutch recipients of the BScc valve were reoperated on based on the results of the Dutch BScc follow-up study, ${ }^{3}$ a decision analysis of the data, ${ }^{7}$ or sometimes the explicit wish of a patient to have the valve explanted.

In this study we report on perioperative morbidity and mortality and long-term survival in patients who had prophylactic replacement of their BScc valve in The Netherlands.

\section{Patients and methods}

Patients. Data were recorded at all cardiac surgery centers in The Netherlands. All patients who underwent prophylactic replacement of their BScc valve before August 1995 were included in this study. If documented, the considerations, including a possible formal decision analysis ${ }^{7}$ for the prophylactic replacement of each of the BScc valve(s), were recorded from the patient records and a comprehensive clinical profile, including relevant aspects of the medical history, details of physical examination, 
Table I. Characteristics of patients that underwent prophylactic replacement

\begin{tabular}{|c|c|c|c|c|c|c|c|c|c|c|c|}
\hline \multirow[b]{2}{*}{ Sex } & \multirow[b]{2}{*}{ Age } & \multicolumn{3}{|c|}{ Valve } & \multirow[b]{2}{*}{$\begin{array}{l}\text { Primary } \\
\text { reason }\end{array}$} & \multirow[b]{2}{*}{$\begin{array}{l}\text { Secondary } \\
\text { reason }\end{array}$} & \multirow[b]{2}{*}{$\begin{array}{l}\text { Medical history and } \\
\text { preoperative findings }\end{array}$} & \multirow[b]{2}{*}{$\begin{array}{l}\text { Concomitant } \\
\text { surgery }\end{array}$} & \multirow[b]{2}{*}{$\begin{array}{l}\text { Perioperative } \\
\text { complications }\end{array}$} & \multirow[b]{2}{*}{$\begin{array}{c}\text { Follow- } \\
\text { up }\end{array}$} & \multirow[b]{2}{*}{ Status } \\
\hline & & Position & $\begin{array}{c}\text { Angle } \\
\text { (degree) }\end{array}$ & Size & & & & & & & \\
\hline Male & 26 & A & 60 & 21 & $\mathrm{R}$ & - & - & - & - & 8 days & Dead \\
\hline Female & 68 & A & 60 & 21 & $\mathrm{R}$ & - & - & - & - & $22 \mathrm{mo}$ & Alive \\
\hline Male & 41 & A & 60 & 23 & $\mathrm{R}$ & PVL & History of endocarditis & - & - & $25 \mathrm{mo}$ & Alive \\
\hline Male & 63 & A & 60 & 23 & $\mathrm{R}$ & - & - & - & - & $39 \mathrm{mo}$ & Alive \\
\hline Female & 29 & A & 60 & 25 & $\mathrm{R}$ & PVL & $\begin{array}{l}\text { Marfan's disease } \\
\text { VSD closed (1975) } \\
\text { Enlargement of aortic } \\
\text { valve (1978) }\end{array}$ & - & - & $17 \mathrm{mo}$ & Alive \\
\hline Male & 35 & A & 60 & 25 & $\mathrm{~W}$ & PVL & History of endocarditis & - & $\begin{array}{l}\text { Complete } \\
\text { AV block } \\
\text { (pacemaker } \\
\text { necessary) }\end{array}$ & $29 \mathrm{mo}$ & Alive \\
\hline Male & 40 & A & 60 & 25 & $\mathrm{R}$ & - & $\begin{array}{l}\text { Prior reoperation for } \\
\text { PVL (1983) } \\
\text { Preoperative finding: } \\
\text { PVL }\end{array}$ & $\begin{array}{l}\text { Reconstruction } \\
\text { anterior mi- } \\
\text { tral leaflet }\end{array}$ & - & $22 \mathrm{mo}$ & Alive \\
\hline Male & 46 & A & 60 & 27 & $\mathrm{R}$ & - & History of endocarditis & & - & $14 \mathrm{mo}$ & Alive \\
\hline Male & 51 & A & 60 & 27 & $\mathrm{~W}$ & - & $\begin{array}{l}\text { Strut fracture mitral } \\
\text { valve (1990) with } \\
\text { complicated postop- } \\
\text { erative course* }\end{array}$ & - & - & $45 \mathrm{mo}$ & Alive \\
\hline Male & 41 & A & 60 & 29 & $\mathrm{R}$ & - & - & - & - & $35 \mathrm{mo}$ & Alive \\
\hline Female & 47 & M & 60 & 27 & $\mathrm{R}$ & - & - & - & - & $24 \mathrm{mo}$ & Dead \\
\hline Female & 46 & $\mathrm{M}$ & 60 & 31 & $\mathrm{R}$ & - & - & - & - & $19 \mathrm{mo}$ & Alive \\
\hline Female & 58 & M & 60 & 31 & $\mathrm{~W}$ & - & - & - & - & $34 \mathrm{mo}$ & Alive \\
\hline Male & 36 & $\begin{array}{l}\mathrm{A} \\
\mathrm{M}\end{array}$ & $\begin{array}{l}60 \\
60\end{array}$ & $\begin{array}{l}23 \\
31\end{array}$ & $\mathrm{R}$ & - & - & - & - & $30 \mathrm{mo}$ & Alive \\
\hline Female & 40 & A & $\begin{array}{c}\text { Spherical } \\
60\end{array}$ & $\begin{array}{l}19 \\
27\end{array}$ & $\mathrm{R}$ & - & - & - & $\begin{array}{l}\text { Transfusion re- } \\
\text { action-multi- } \\
\text { organ failure } \\
\text { and excessive } \\
\text { bleeding }\end{array}$ & 42 mo & Alive \\
\hline Male & 47 & A & 70 & 23 & $\mathrm{R}$ & - & - & - & - & $3 \mathrm{mo}$ & Alive \\
\hline Male & 54 & A & 70 & 23 & W & - & - & - & - & $89 \mathrm{mo}$ & Alive \\
\hline Male & 26 & A & 70 & 27 & $\mathrm{R}$ & PVL & - & $\begin{array}{r}\text { Replacement } \\
\text { aortic root }\end{array}$ & - & $34 \mathrm{mo}$ & Alive \\
\hline Male & 42 & A & 70 & 27 & $\mathrm{R}$ & - & - & - & $\begin{array}{l}\text { Prolonged unex- } \\
\text { plained fever } \\
\text { and acute } \\
\text { hepatitis }\end{array}$ & $41 \mathrm{mo}$ & Alive \\
\hline
\end{tabular}

$A$, Aortic; $A V$, atrioventricular; $C A D$, coronary artery disease; $M$, mitral; $P V L$, paravalvular leakage; $R$, high fracture risk; $T I A$, transient ischemic attack; $V S D$, ventricular septal defect; $W$, patient's explicit wish to have the valve explanted.

*The BScc aortic valve was not replaced during the emergency procedure after strut fracture of the mitral valve in 1990.

cardiac catheterization and/or echocardiography, and, if performed, coronary angiography. Also, the type of surgical procedure, possible concomitant procedures, perioperative, and postoperative complications were recorded.

Prophylactic replacement. A replacement was judged to be prophylactic if either the treating cardiac surgeon or cardiologist considered the risk of outlet strut fracture for that individual patient higher than his or her risk of death from reoperation, or if the patient wished to have the valve replaced although replacement was not directly advised by his or her cardiac surgeon and cardiologist. If a concomitant pathologic condition was already present before replacement of the valve was considered, but was not likely to require cardiac surgery in the near future, the reoperation was still considered prophylactic. This was also true if preoperative examination revealed an unexpected cardiac pathologic condition.

Follow-up. Follow-up data on functional and vital status were collected from the clinical records and the municipality registers. Early mortality was defined as death occurring within 30 days or before hospital discharge. The cause of death was determined on the basis of medical records from the hospital (including autopsy reports if present) or the patient's general practitioner. 
Table I. Cont'd

\begin{tabular}{|c|c|c|c|c|c|c|c|c|c|c|c|}
\hline \multirow[b]{2}{*}{$\operatorname{Sex}$} & \multirow[b]{2}{*}{ Age } & \multicolumn{3}{|c|}{ Valve } & \multirow[b]{2}{*}{$\begin{array}{l}\text { Primary } \\
\text { reason }\end{array}$} & \multirow[b]{2}{*}{$\begin{array}{l}\text { Secondary } \\
\text { reason }\end{array}$} & \multirow[b]{2}{*}{$\begin{array}{l}\text { Medical history and } \\
\text { preoperative findings }\end{array}$} & \multirow[b]{2}{*}{$\begin{array}{l}\text { Concomitant } \\
\text { surgery }\end{array}$} & \multirow[b]{2}{*}{$\begin{array}{l}\text { Perioperative } \\
\text { complications }\end{array}$} & \multirow[b]{2}{*}{$\begin{array}{l}\text { Follow- } \\
\text { up }\end{array}$} & \multirow[b]{2}{*}{ Status } \\
\hline & & Position & $\begin{array}{c}\text { Angle } \\
\text { (degree) }\end{array}$ & Size & & & & & & & \\
\hline Male & 50 & A & 70 & 27 & $\mathrm{R}$ & - & - & - & - & $36 \mathrm{mo}$ & Alive \\
\hline Male & 54 & A & 70 & 27 & $\mathrm{R}$ & - & Amaurosis fugax (1970) & - & - & $32 \mathrm{mo}$ & Alive \\
\hline Male & 60 & A & 70 & 27 & $\mathrm{R}$ & - & - & - & $\begin{array}{l}\text { Complete } \\
\text { AV block } \\
\text { (pacemaker } \\
\text { necessary) }\end{array}$ & $35 \mathrm{mo}$ & Alive \\
\hline Male & 64 & A & 70 & 27 & $\mathrm{R}$ & - & - & - & - & 47 days & Dead \\
\hline Male & 66 & A & 70 & 27 & $\mathrm{R}$ & - & - & - & - & $40 \mathrm{mo}$ & Alive \\
\hline Male & 48 & A & 70 & 29 & W & - & - & - & - & $39 \mathrm{mo}$ & Alive \\
\hline Male & 62 & A & 70 & 29 & W & - & - & - & - & $90 \mathrm{mo}$ & Alive \\
\hline Male & 66 & A & 70 & 29 & $\mathrm{R}$ & - & - & - & - & 36 mo & Alive \\
\hline Female & 43 & M & 70 & 27 & $\mathrm{R}$ & - & - & - & - & 25 days & Alive \\
\hline Female & 47 & M & 70 & 27 & $\mathrm{R}$ & - & $\begin{array}{l}\text { History of myocardial } \\
\text { infarction, TIA, and } \\
\text { lung embolism; open } \\
\text { commisurotomy mi- } \\
\text { tral valve (1978); } \\
\text { severe tricuspid re- } \\
\text { gurgitation }\end{array}$ & - & - & $41 \mathrm{mo}$ & Alive \\
\hline Female & 30 & M & 70 & 29 & $\mathrm{R}$ & - & $\begin{array}{l}\text { Prior mitral valve re- } \\
\text { placement (1979) }\end{array}$ & - & - & $32 \mathrm{mo}$ & Alive \\
\hline Female & 53 & M & 70 & 29 & $\mathrm{R}$ & - & - & - & - & $41 \mathrm{mo}$ & Alive \\
\hline Female & 65 & M & 70 & 29 & $\mathrm{R}$ & - & - & - & - & $44 \mathrm{mo}$ & Alive \\
\hline Male & 46 & M & 70 & 31 & $\mathrm{R}$ & - & $\begin{array}{l}\text { Prior mitral valve re- } \\
\text { placement (1979); } \\
\text { history of endocardi- } \\
\text { tis }\end{array}$ & - & - & $17 \mathrm{mo}$ & Alive \\
\hline Female & 63 & M & 70 & 31 & $\mathrm{R}$ & - & $\begin{array}{l}\text { Closed commisur- } \\
\text { otomy mitral valve } \\
(1958)\end{array}$ & - & - & $39 \mathrm{mo}$ & Alive \\
\hline Female & 64 & M & 70 & 31 & $\mathrm{R}$ & - & TIA (1978); CAD & $\begin{array}{l}\text { Coronary ar- } \\
\text { tery bypass } \\
\text { grafting }\end{array}$ & - & $38 \mathrm{mo}$ & Alive \\
\hline Male & 66 & $\begin{array}{l}\text { A } \\
\mathrm{M}\end{array}$ & $\begin{array}{l}70 \\
70\end{array}$ & $\begin{array}{l}25 \\
29\end{array}$ & W & - & $\begin{array}{l}\text { History of endocardi- } \\
\text { tis; CAD }\end{array}$ & $\begin{array}{l}\text { Coronary ar- } \\
\text { tery bypass } \\
\text { grafting }\end{array}$ & - & $38 \mathrm{mo}$ & Alive \\
\hline
\end{tabular}

Data analysis. Proportions are presented with an exact 95\% CI. ${ }^{9}$ Cumulative survival was estimated by the Kaplan-Meier product limit method. ${ }^{10}$

\section{Results}

Until August 199537 Dutch BScc valve recipients from nine centers underwent prophylactic replacement of their valves; on one surviving patient no further data were available. The BScc valves of 29 patients were explanted because the treating cardiac surgeon and cardiologist thought that prophylactic replacement compared favorably with expectant management; formal decision analysis was used to support this decision in nine of these patients. Seven patients insisted on having their valves replaced, although replacement was not directly recommended by their physicians.

Table I shows patient and surgical characteristics. The series consisted of 23 men and 13 women. The mean age was 49 years ( \pm 12 standard deviation; extremes 26 to 68 years). Five patients had a history of endocarditis. Before reoperation, all patients were in New York Heart Association functional class I or II. At preoperative screening, angiography demonstrated severe tricuspid regurgitation in one patient, coronary artery disease in two patients, and paravalvular leakage in five patients.

Twenty-two aortic valve replacements, 11 mitral valve replacements, and three double-valve replacements were performed. Ten large-size $(\geq 29 \mathrm{~mm})$ 
and 12 small-size $(<29 \mathrm{~mm})$ 70-degree BScc valves and four large-size and 12 small-size 60 -degree BScc valves were replaced. Concomitant procedures comprised tricuspid valve plasty in one patient, coronary artery bypass grafting in two patients, reconstruction of the previously damaged anterior mitral leaflet in one patient, and replacement of the aortic root by a homograft in one patient.

All patients survived the reoperation without technical problems. Four patients had postoperative complications (Table I). At hospital discharge no persistent neurologic deficits were documented. The median length of hospital stay was 11 days and ranged from 8 days to 267 days. The mean follow-up was 33 months (extremes 8 days to 90 months).

One patient died $(2.8 \%$, exact $95 \%$ CI $0.1 \%$ to $14.5 \%), 8$ days after the operation after just having been released from the hospital. Two patients died later during follow-up at 47 days and at 745 days, respectively. All three patients died suddenly. An autopsy was performed in one of these deaths and no cause of death could be determined. The survival was $94 \%$ at 12 months (95\% CI $79 \%$ to $99 \%$ ) and declined to $91 \%$ at 36 months $(95 \%$ CI $74 \%$ to $97 \%)$.

\section{Discussion}

The patients described in this study represent a carefully selected group of patients because the treating cardiac surgeon weighed the risk of outlet strut fracture against the individual risk of morbidity or mortality from reoperation for each of these patients to the best of his or her abilities. The risk estimates applied by the cardiac surgeons were based on the available literature at that time $e^{3,6-8,11-14}$ and on institution-specific experiences with rereplacement of prosthetic heart valves. Except for the patients who wished to have their valve replaced, the cardiac surgeons believed the risk of outlet strut fracture outweighed that reoperation. The fact that decision analytic support was used for only nine patients to support the decision to explant the BScc valve does not mean that the decision making was less prudent in the other patients; it merely reflects the decision process in clinical practice and underscores the fact that many obstacles to the understanding and acceptance of formal decision analysis still exist. ${ }^{15-17}$

The results from our study add significantly to the understanding of risks associated with prophylactic replacement of artificial valves after several other studies with subgroups of similarly young patients undergoing elective valve reoperation have been published. ${ }^{13,18}$ Contrary to patients undergoing prophylactic replacement, those undergoing elective replacement always have some underlying heart condition requiring valve replacement at that moment. Furthermore, in contrast to our study, these studies only reported on in-hospital mortality. Little has been written on the operative risk associated with prophylactic replacement of artificial heart valves. The few studies that actually dealt with prophylactic replacement of well-functioning artificial heart valves concerned Braunwald-Cutter aortic prostheses (Cutter Biological, Berkeley, Calif.) and date almost 20 years back. ${ }^{11,12}$ Prophylactic replacement of these valves, because of predicted failure, seemed to be associated with a low risk of perioperative mortality. In the past prophylactic replacement of BScc valves was advised for selected groups of patients. ${ }^{3,4,7}$ Some authors have claimed that elective replacement of BScc valves, because of its inherent morbidity and mortality, cannot be recommended. ${ }^{19-21}$ Other clinical studies, however, have suggested that reoperative valvular surgery in an elective setting has perioperative morbidity and mortality similar to initial valve replacement. ${ }^{12-14,18}$ Early mortality in this study was similar to that of primary valve replacement in our original cohort ${ }^{3}$ and in accordance with what was assumed in several decision analyses ${ }^{4,7}$ and therefore seems acceptable, especially because six patients $(17 \%)$ were reoperated on previously. However, the one patient who died early was a 26-year-old man in perfect health before the operation. The sudden death of another 64-year-old patient, 47 days after the operation, most likely was also related to the procedure. If this death would be accounted for as operative death, the operative mortality would increase to $5.6 \%$ (95\% exact CI $0.7 \%$ to $18.7 \%$ ). Furthermore, all deaths in this study were sudden. Sudden death has been found to be the second most common mode of death in patients undergoing primary valve replacement. ${ }^{1}$ Despite the small number of events, the sudden death rate in this study during the first year of follow-up was 7.8 (95\% CI $1.8 \%$ to $34.0 \%$; Cox regression) times higher than in our original cohort study. ${ }^{3}$ Given the small number of patients in this study, it remains highly speculative whether this was a chance finding or whether prophylactic replacement really carries a higher risk of sudden death. More data are needed to assess the risk of sudden death after prophylactic replacements. On the other hand, BScc valves still fracture. Forty-six fractures 
had been documented until August 1995. Six large fractures $(\geq 29 \mathrm{~mm}$ ) 60-degree BScc valves (five mitral and one aortic) were reported after the closing date of this study.

Thus prophylactic replacement still seems advisable for selected subgroups of BScc valve recipients, but evidence from this study indicates that proper decision making is warranted.

\section{REFERENCES}

1. Blackstone EH, Kirklin JW. Death and other time-related events after valve replacement. Circulation 1985;72:753-67.

2. Christakis GT, Weisel RD, David TE, Salerno TA, Ivanov J. Predictors of operative survival after valve replacement. Circulation 1988;78(Suppl):I25-34.

3. van der Graaf Y, de Waard F, van Herwerden LA, Defauw J. Risk of strut fracture of Björk-Shiley valves. Lancet 1992;339: 257-61.

4. Birkmeyer JD, Marrin CA, O'Connor GT. Should patients with Björk-Shiley valves undergo prophylactic replacement? Lancet 1992;340:520-3.

5. Marrin CA, Birkmeyer JD, O'Connor GT. The Björk-Shiley dilemma [editorial]. Ann Thorac Surg 1993;55:1361-4.

6. Lindblom D, Rodriguez L, Björk VO. Mechanical failure of the Björk-Shiley valve: updated follow-up and considerations on prophylactic rereplacement. J Thorac Cardiovasc Surg 1989;97:95-7.

7. van der Meulen JH, Steyerberg EW, van der Graaf Y, et al. Age thresholds for prophylactic replacement of Björk-Shiley convexo-concave heart valves: a clinical and economic evaluation. Circulation 1993;88:156-64.

8. Ericsson A, Lindblom D, Semb G, et al. Strut fracture with Björk-Shiley 70 degrees convexo-concave valve: an international multi-institutional follow-up study. Eur J Cardiothorac Surg 1992;6:339-46.

9. Binomialverteilung. Exakte Vertrauensgrenzen. In: Diem K, editor. Documenta Geigy Wissenschaftliche Tabellen. Basel: Geigy, J.R.;1960. p. 85-98.

10. Kaplan EL, Meier P. Nonparametric estimation from incomplete observations. J Am Stat Assoc 1958;53:457-81.

11. Blackstone EH, Kirklin JW, Pluth JR, Turner ME, Parr GV. The performance of the Braunwald-Cutter aortic prosthetic valve. Ann Thorac Surg 1977;23:302-18.
12. Husebye DG, Pluth JR, Piehler JM, et al. Reoperation on prosthetic heart valves: an analysis of risk factors in 552 patients. J Thorac Cardiovasc Surg 1983;86:543-52.

13. Bosch X, Pomar JL, Pelletier LC. Early and late prognosis after reoperation for prosthetic valve replacement. J Thorac Cardiovasc Surg 1984;88:567-72.

14. de Bruin MJ, Lacquet LK, Skotnicki SH, Vincent JG, van der Meer JJ. Reoperation for prosthetic heart valve replacement. Thorac Cardiovasc Surg 1986;34:12-6.

15. Schwartz WB. Decision analysis: a look at the chief complaints. N Engl J Med 1979;300:556-9.

16. Cebull RD. "A look at the chief complaints" revisited: current obstacles and opportunities for decision analysis. Med Decis Making 1984;4:271-83.

17. Balla JI, Elstein AS, Christensen C. Obstacles to acceptance of clinical decision analysis. BMJ 1989;298:579-82.

18. Piehler JM, Blackstone EH, Bailey KR, Sullivan ME, Pluth JR, Weiss NS, et al. Reoperation on prosthetic heart valves: patient-specific estimates of in-hospital events. J Thorac Cardiovasc Surg 1995;109:30-48.

19. Treasure T. Management of patients with Björk-Shiley prosthetic valves [editorial]. Br Heart J 1991;66:333-34.

20. Hiratzka LF, Kouchoukos NT, Grunkemeier GL, Miller DC, Scully HE, Wechsler AS. Outlet strut fracture of the BjörkShiley 60 degrees convexo-concave valve: current information and recommendations for patient care. J Am Coll Cardiol 1988;11:1130-7.

21. Schönhube FA, Althoff WA, Dörge HC, et al. Prophylactic replacement for strut fractures of the Björk-Shiley convexoconcave heart valve. J Heart Valve Dis 1994;3:247-53.

\section{Appendix}

Participating centers: Academisch Medisch Centrum (BAJM de Mol; 2 patients), Onze Lieve Vrouwe Gasthuis Amsterdam (L Eijsman; 11 patients), Academisch Ziekenhuis Leiden (H Huysmans; 1 patient), Dijkzigt Ziekenhuis Rotterdam (LA van Herwerden; 5 patients), Academisch Ziekenhuis Utrecht (JJ Bredee; 1 patient), Sint Antonius Ziekenhuis Nieuwegein (JJAMT Defauw; 12 patients), Medisch Centrum de Klokkenberg (ThR van Geldorp; 3 patients), Ziekenhuis de Weezenlanden Zwolle (MMP Haalebos; 1 patient). 